\title{
METODE PEMBELAJARAN SNOWBALL DRILLING UNTUK MENINGKATKAN HASIL BELAJAR SISWA KELAS VIII MTs. NEGERI NGADA
}

\author{
Eni Syafitri ${ }^{1}$, Gregorius Taga ${ }^{2}$, Stefania Baptis Seto ${ }^{3}$ \\ ${ }^{1}$ Program Studi Pendidikan Matematika Universitas Flores, Jl. Samratulangi, Ende-Flores-NTT \\ ${ }^{2}$ Universitas Flores, Jl.Samratulangi, Ende-Flores-NTT \\ ${ }^{3}$ Universitas Flores, Jl. Samratulangi, Ende-Flores-NTT \\ Syafitrieni47@gmail.com
}

\begin{abstract}
This study aims to (1) produce a snowball drilling learning tool for relation and function material for class VIII students of MTs. Negeri Ngada Academic Year 2020/2021; (2) improve learning outcomes through snowball drilling for relation and function material for class VIII of MTs. Negeri Ngada Academic Year 2020/2021. The type of research used experimental research with a quantitative approach. The research procedure began by prepared learning tools included RPP, LKS, THB. After conducted the trial phase, the learning device has meets the requirements for validity, reliability, sensitivity, and was suitable for used in research. Sources of data this research were obtained from student learning outcomes test in the from of pre-test and post-test. The research data were processed using Anacova (analysis of variances) statistical analysis. From the result of the development of learning tools snowball drilling for relation and functions material, a good learning tool is produced. Based on the result of covariance analysis, it was obtained that $F_{\text {count }}=17.43823$ and $F_{\text {table }}=$ $4.21\left(F_{\text {count }}>F_{\text {table }}\right)$ with $d k$ numerator 1 and $d k$ denominator $=27$ give a significant value. This shows that the snowball drilling learning method is considered to improve learning outcomes for relation and function material.
\end{abstract}

Keywords: Snowball Drilling Learning Method; Relation And Function Material

\begin{abstract}
Abstrak
Penelitian ini bertujuan untuk (1) menghasilkan perangkat pembelajaran snowball drilling untuk materi relasi dan fungsi pada siswa kelas VIII MTs. Negeri Ngada Tahun Pelajaran 2020/2021; (2) meningkatkan hasil belajar melalui pembelajaran snowball drilling untuk materi relasi dan fungsi pada siswa kelas VIII MTs. Negeri Ngada. Jenis penelitian yang digunakan adalah penelitian eksperimen dengan pendekatan kuantitatif. Prosedur penelitian dimulai dengan menyiapkan perangkat pembelajaran antara lain RPP, LKS, THB. Setelah melakukan tahap uji coba, perangkat pembelajaran telah memenuhi syarat validitas, reliabilitas, sensitivitas, dan layak digunakan dalam penelitian. Sumber data dalam penelitian ini diperoleh dari tes hasil belajar siswa berupa pre-test dan post-test. Data hasil penelitian diolah menggunakan analisis statistik Anakova. Dari hasil pengembangan perangkat pembelajaran snowball drilling untuk materi relasi dan fungsi, dihasilkan perangkat pembelajaran yang baik. Berdasarkan hasil analisis kovarian diproleh $\mathrm{F}_{\text {hitung }}=17.43823$ dan $\mathrm{F}_{\text {tabel }}=4.21\left(\mathrm{~F}_{\text {hitung }}>\mathrm{F}_{\text {tabel }}\right)$ dengan $\mathrm{dk}$ pembilang $=1$ dan dk penyebut $=27$, memberikan nilai yang signifikan. Hal ini menunjukan bahwa metode pembelajaran snowball drilling dinilai dapat meningkatkan hasil belajar untuk materi relasi dan fungsi.
\end{abstract}

Kata kunci: Metode Snowball Driiling; relasi dan fungsi. 
Metode Pembelajaran Snowball Drilling Untuk Materi Relasi dan Fungsi Pada Siswa Kelas VIII MTs. Negeri Ngada Eni Syafitri ${ }^{1}$ Gregorius Taga ${ }^{2}$, Stefania Baptis Seto ${ }^{3}$

Jupika: Jurnal Pendidikan Matematika, Volume 4. Nomor 1. Maret 2021. Hal. 42-51

\section{PENDAHULUAN}

Hasil belajar siswa pada masa kini masih masih tergolong rendah, terutama pada pelajaran matematika. Hal ini disebabkan karena mereka menganggap pelajaran matematika adalah salah satu matapelajaran yang sulit. Oleh karena itu peran guru sangat penting dalam meningkatkan kualitas pembelajaran, baik kualitas proses maupun kualitas lulusan. Sebagai pendidik, guru harus menarik dihadapan peserta didiknya dan sebagai pendidik guru harus menjadi pelajar yang baik, manusia yang berkualitas dan berkepribadian unggul. Dalam kondisi apapun guru harus menjadi panutan bagi peserta didik (Mulyasana, 2011).

Berdasarkan pengalaman selama proses Praktek Pengalaman Lapangan (PPL) yang telah dilakukan, ditemukan bahwa siswa-siswi masih mengalami kesulitan dalam proses pembelajaran matematika. Siswa cenderung pasif dalam menanggapi pembelajaran yang sedang berlangsung. Hal tersebut mengakibatkan hasil belajar siswa rendah. Selain mengalami kesulitan dalam proses pembelajaran, siswa juga sulit untuk mengakses sumber belajar dikarenakan fasilitas belajar yang masih kurang memadai. Hal tersebut juga mempengaruhi rendahnya hasil belajar, serta menuntut guru untuk lebih kreatif dalam memberikan pembelajaran. Adapun salah satu metode pembelajaran yang cukup efektif dalam meningkatkan motivasi, partisipasi aktif, serta hasil belajar siswa adalah metode snowball drilling (Suprijono, 2014) Pengetahuan yang kuat dan dapat dikembangkan secara baik bisa dilakukan dengan mnggunakan metode snowball drilling.

Menurut ningsih, dkk. (2014) Snowball drilling adalah suatu metode pembelajaran yang memberikan latihan soal pada setiap anggota. Jika anggota dalam kelompok yang ditunjuk dapat menyelesaikan soal maka meraka dapat menunjuk anggota kelompok lain untuk menyelesaikan soal selanjutnya. Metode pembelajaran snowball drilling merupakan pebelajaran yang di tujukan guna guru dapat meningkatkan kemampuan atau pengetahuan peserta didik yang diperoleh pada saat pembelajaran, metode snowball drilling menuntut siswa agar mampu menjawab soal yang sudah disediakan oleh guru dengan sungguh-sungguh dan benar (Suprijono, 2014). Hal ini sejalan dengan Larasati, dkk. (2020) pada pembelajaran snowball drilling siswa dituntut untuk mengerjakan paket soal yang telah disediakan oleh guru.

Berdasakan penelitian terdahulu yang dilakukan oleh Haryani, dkk. (2015), hasil belajar matematika siswa kelas VIII SMP Negeri H Wukirsari setelah penerapan metode snowball drilling secara signifikan sudah tuntas. Pada penelitian Chalimatus (2018), penerapan pembelajaran snowball drilling mampu meningkatkan hasil belajar siswa, dan rasa percaya diri dalam menjawab soal serta mampu menciptakan suasana pembelajaran yang menyenangkan.

Pembelajaran adalah suatu usaha sadar dari guru dalam kegiatan belajar siswa melalui interaksi-interaksi yang terjadi selama proses pembelajaran yang dirancang sedemikian rupa sesuai dengan tujuan yang ingin dicapai yang memenuhi bidang kognitif, afektif, dan psikomotorik serta mampu menghasilkan keluaran berupa perubahan tingkah laku yang lebih baik dalam diri siswa. 
Metode Pembelajaran Snowball Drilling Untuk Materi Relasi dan Fungsi Pada Siswa Kelas VIII MTs. Negeri Ngada Eni Syafitri ${ }^{1}$ Gregorius Taga ${ }^{2}$, Stefania Baptis Seto ${ }^{3}$

Jupika: Jurnal Pendidikan Matematika, Volume 4. Nomor 1. Maret 2021. Hal. 42-51

Dalam gambaran kelas pada masa mendatang, Gary Flewelling dan William Higginson (Suyono dan Hariyanto, 2011) menjelaskan peran guru sebagai berikut :

a. Memberikan stimulus kepada siswa dengan memberikan soal latihan yang terancang dengan baik dalam meningkatkan perkembangan kognitif, psikomotorik, afektif.

b. Berinteraksi dengan siswa untuk mendorong keberanian, mengilhami, menantang, berdiskusi, berbagi, menjelaskan, menegaskan, merefleksi, menilai, dan merayakan perkembangan, pertumbuhan, dan keberhasilan.

c. Menunjukan manfaat yang diperoleh dari suatu pokok bahasan.

Dengan Metode snowball drilling dapat menguatkan pengetahuan peserta didik dari materi yang telah dipelajari (Suprijono, 2014). Metode snowball drilling mampu menciptakan kondisi proses mental yang positif, sehingga dapat menarik perhatian peserta didik untuk belajar, menumbuhkan percaya diri dan rasa kepuasan dalam diri peserta didik terhadap hal yang dipelajarinya sehingga mampu meningkatkan hasil belajar siswa (Prabu, 2011). Snowball drilling menuntut siswa untuk fokus dan perhatian yang tinggi dalam proses kegiatan belajar, melatih kecekatan siswa dalam menjawab soal dengan benar dan cepat (Larasati, dkk. 2020). Model pembelajaran tipe Snowball Drilling ini dipilih karena pada model pembelajaran ini adalah model pembelajaran yang akan memberikan penguatan materi pelajaran kepada peserta didik berupa pemberian soal- soal latihan menyangkut materi yang telah diberikan sebelumnya sehingga diharapkan mampu menambah pemahaman peserta didik, selain itu model pembelajaran ini juga akan meningkatkan interaksi antara peserta didik dengan guru sehingga diharapkan peserta didik lebih bersemangat dan berkonsentrasi dalam mengikuti pelajaran (Yanto, 2014).

Dalam penerapan metode snowball drilling, peran guru adalah mempersiapkan paket soal dan lembar skorsing (penilaian) yang di share kepada siswa serta menggelindingkan bola salju berupa soal latihan dengan cara menunjuk/mengundi untuk mendapatkan siswa yang akan menjawab soal nomor satu. Siswa yang mendapat giliran pertama menjawab soal tersebut maka akan diberi kesempatan menunjuk salah satu temannya menjawab soal nomor berikutnya yaitu soal nomor dua. Seandainya siswa yang pertama mendapat kesempatan menjawab soal nomor satu gagal maka siswa itu diharuskan menjawab soal berikutnya dan seterusnya hingga siswa tersebut berhasil menjawab benar item soal pada suatu nomor soal tertentu (Suprijono, 2014).

Menurut Suprijono (2014), langkah-langkah metode snowball drilling sebagai berikut:

1. Guru menjelaskan inti dari materi yang sedang dipelajari

2. Guru mempersiapkan paket soal

3. Guru atau siswa memilih paket soal latihan

4. Guru memberikan waktu bagi peserta didik untuk menjawab paket soal yang terpilih

5. Guru menunjuk/mengundi salah satu siswa untuk menjawab paket soal tersebut 
6. Jika siswa yang terpilih menjawab dengan benar, maka siswa itu diberikan kesempatan menunjuk salah satu temannya untuk menjawab soal berikutnya. Tapi jika jawabannya salah maka dengan bimbingan guru, siswa tersebut harus menjawab soal berikutnya hingga berhasil menjawab soal dengan benar

7. Guru memberikan penguatan kepada peserta didik tentang materi yang dipelajari.

\section{METODE}

Jenis penelitian ini adalah penelitian eksperimen yang diawali dengan pengembangan perangkat pembelajaran berupa Rencana Perangkat Pembelajaran (RPP), Lembar Kerja Siswa (LKS), dan pengembangan instrumen penelitian berupa Tes Hasil Belajar (THB), sedangkan pendekatan penelitian yang digunakan adalah pendekatan kuantitatif. Penelitian ini dilaksanakan di MTs. Negeri Ngada, Kelurahan Nangamese, Kecamatan Riung Kabupaten Ngada. Penelitian dilaksanakan pada bulan Agustus 2020. Rancangan penelitian yang digunakan adalah one group pre-test dan pos-test seperti pada tabel di bawah ini :

Tabel 1

Rancangan Penelitian

\begin{tabular}{|l|l|l|l|}
\hline Kelas & Tes Awal & Perlakuan & Tes Akhir \\
\hline Eksperimen & $\mathrm{Q}_{1}$ & $\mathrm{X}$ & $\mathrm{Q}_{2}$ \\
\hline
\end{tabular}

Sumber: Sugiyono (2010:111)

Populasi dalam penelitian ini adalah peserta didik kelas VIII MTs. Negeri Ngada Tahun Pelajaran 2020/2021. Untuk menentukan jumlah sampel peneliti berpedoman pada pendapat Sugiyono yaitu dengan teknik pengambilan Sampling Purposive (pengambilan dengan pertimbangan) (Sugiyono, 2010: 116). Jadi sampel tidak diambil secara acak tetapi ditentukan sendiri oleh peneliti. Sampel dalam penelitian ini adalah kelas VIII A.

Dalam penelitian ini teknik yang digunakan peneliti dalam mengumpulkan data adalah sebagai berikut :

a. Observasi

Observasi adalah salah satu Teknik pengumpulan data yang membantu peneliti dalam melaksanakan penelitian secara langsung situasi dan kondisi yang terjadi pada lapangan (Sugiyono, 2007).

b. Dokumentasi

Dalam penelitian ini dokumentasi digunakan untuk mendapatkan data tentang kondisi objektif dan mengetahui hasil belajar siswa.

c. Tes

Tes adalah instrument atau alat ukur yang diberikan kepada responden dalam bentuk pertanyaan yang harus dijawan oleh responden itu sendiri (Arifin, 2012). Tes yang 
digunakan dalam penelitian ini adalah untuk mengetahui kemampuan siswa dalam menyelesaikan soal-soal yaitu tes tertulis.

Untuk menganalisis data hasil penelitian ini, digunakan analisis kovarian. Data yang dianalisis adalah data hasil pre-test ( kemampuan awal siswa) sebagai variabel penyerta atau konkomitan dan data hasil post-test (hasil belajar siswa sesudah pembelajaran) sebagai variabel terikat. Analisis kovarian dalam desain eksperimen merupakan perkawinan antara regresi dan analisis varians (Kurtner dkk, 2005).

\section{HASIL DAN PEMBAHASAN}

Berdasarkan rumusan masalah penelitian maka langkah pertama yang dilakukan oleh peneliti adalah merancang perangkat pembelajaran yang berdasarkan pada sintaks pembelajaran snowball drilling. Perangkat pembelajaran dimaksud adalah (1) Rencana Pelaksanaan Pembelajaran (RPP), (2) Lembar Kerja Siswa (LKS), dan (3) Tes Hasil Belajar (THB). Selanjutnya perangkat pembelajaran yang telah dirancang tersebut divalidasi oleh validator pada tanggal 05 Agustus 2020, dalam hal ini yang menjadi validator adalah dosen pendidikan matematika. Berikut hasil perhitungan uji validitas, reliabilitas, dan sensitivitas butir soal yang diperoleh dari hasil pre-test dan post- test siswa pada kelas uji coba.

\section{Tabel 2}

\section{Validitas Butir THB}

\begin{tabular}{|c|c|c|c|c|c|}
\hline No. Soal & $\mathbf{1}$ & $\mathbf{2}$ & $\mathbf{3}$ & $\mathbf{4}$ & $\mathbf{5}$ \\
\hline rxy & 0.69697 & 0.781188 & 0.849714 & 0.705156 & 0.590909 \\
\hline Validitas & Tinggi & Tinggi & Sangat Tinggi & Tinggi & Cukup \\
\hline
\end{tabular}

Berdasarkan hasil perhitungan reliabilitas tes diperoleh koefisien reliabilitas sebesar 0.68 kriteria " tinggi “, selengkapnya dapat dilihat pada lampiran. Jadi instrumen penelitian ini memenuhi kriteria reliabel dan dapat digunakan untuk penelitian.

Tabel 3

\section{Sensitivitas Setiap Butir THB}

\begin{tabular}{|c|c|c|c|c|c|}
\hline No. Soal & $\mathbf{1}$ & $\mathbf{2}$ & $\mathbf{3}$ & $\mathbf{4}$ & $\mathbf{5}$ \\
\hline Sensitivitas & 0.7 & 0.72 & 0.733333 & 0.8 & 0.72 \\
\hline Interpretasi & Peka & Peka & Peka & Peka & Peka \\
\hline
\end{tabular}

Berdasarkan kriteria kelayakan butir tes sebagaimana diuraikan dalam bab III, maka setiap butir tes telah memenuhi kriteria valid, reliabel, dan sensitivitas serta dikategorikan layak digunakan dalam penelitian. 
Data hasil pre-test dan post-test siswa dianalisis dengan menggunakan analisis statistik anakova. Tujuannya untuk mengetahui seberapa besar pengaruh dari perlakuan yang diberikan, dalam hal ini adalah pembelajaran snowball drilling yang diberikan kepada siswa.

Tabel 4

Daftar Anakova Metode pembelajaran

\begin{tabular}{|l|c|c|c|c|c|c|c|c|}
\hline \multicolumn{10}{|c|}{ DAFTAR ANAKOVA METODE PEMBELAJARAN } \\
\hline \multirow{2}{*}{$\begin{array}{l}\text { Sumber } \\
\text { Variasi }\end{array}$} & $\mathbf{d k}$ & \multicolumn{2}{|c|}{ JK dan Produk silang } & \multicolumn{3}{c|}{ Dikoreksi } & \\
\cline { 3 - 10 } & & Y & XY & X & Y & dk & KT & F \\
\hline $\begin{array}{l}\text { Antar } \\
\text { Kelompok }\end{array}$ & 1 & 1763.333 & -1035 & 607.5 & & & & \\
\hline $\begin{array}{l}\text { Dalam } \\
\text { Kelompok }\end{array}$ & 28 & 1466.667 & -975 & 1766.667 & 928.577 & 27 & 34.39174 & \\
\hline Jumlah & 29 & 3230 & -2010 & 2374.167 & 1528.308 & 28 & & \\
\hline $\begin{array}{l}\text { Antar } \\
\text { Kelompok }\end{array}$ & & & & & 599.7311 & 1 & 599.7311 & 17.43823 \\
\hline
\end{tabular}

Dari tabel anakova di atas, untuk menguji pengaruh pembelajaran dalam kelompok eksperimen terhadap respon $\mathrm{Y}$ setelah dimurnikan dari variabel konkomitan $\mathrm{X}$, diperoleh statistik $\mathrm{F}_{\text {hitung }}=$ 17.43823 dengan $\mathrm{dk}$ pembilang $=1 \mathrm{dan} \mathrm{dk}$ penyebut $=27$, pada taraf signifikansi $(\alpha=$ 0.05) memberikan nilai $\mathrm{F}$ tabel $=4.21$. Jadi nilai $\mathrm{F}_{\text {hitung }}>\mathrm{F}_{\text {tabel }}$ artinya $\mathrm{H}_{0}$ ditolak dan $\mathrm{H}_{1}$ diterima.

\section{REGRESI DALAM PERLAKUAN}

Dengan memperhatikan model anakova yaitu:

$$
\begin{aligned}
Y_{i j}=\mu+\beta\left(X_{i j}-\bar{X}\right)+\tau_{i}+\varepsilon_{i j} \quad i & =1,2, \ldots, k \\
j & =1,2, \ldots, n_{k},
\end{aligned}
$$

Nilai parameter yang diduga dengan metode kuadrat terkecil:

1. Koefisien regresi $\beta$ ditaksir oleh: $b=\frac{E_{X Y}}{E_{X X}}$

$$
b=-0.55
$$

2. $\mu$ ditaksir oleh: $\frac{J_{Y . .}}{N}$

$$
\mu=\frac{\Sigma y}{n}=52
$$

3. $\tau_{i}$ ditaksir oleh: $\frac{J_{Y i .}}{n_{i}}-b\left(\frac{J_{X i .}}{n_{i}}-\frac{J_{X . .}}{N}\right)$

Perlakuan A $\left(\tau_{A}\right)=46.81682$

Perlakuan B $\left(\tau_{B}\right)=57.18318$ 


\section{Tabel 4.7}

Nilai Rata-rata Kelompok

\begin{tabular}{|c|c|c|}
\hline $\begin{array}{c}\text { Perlakuan } \\
\text { Kelompok }\end{array}$ & Rata-rata dikoreksi & Rata-rata tidak dikoreksi \\
\hline A & 46.81682 & 44.33333 \\
\hline B & 57.18318 & 59.66667 \\
\hline
\end{tabular}

Dari tabel tersebut di atas tampak bahwa perbedaan rata-rata yang dikoreksi atau disesuaikan harga-harganya lebih kecil perbedaannya dari yang satu dengan yang lainnya jika dibandingkan dengan rata-rata yang tidak dikoreksi.

Model yang diperoleh dalam eksperimen adalah:

$$
\begin{aligned}
& Y_{A}=52-0,55 x+46,82 \\
& Y_{B}=52-0,55 x+57,18
\end{aligned}
$$

Setelah diperoleh nilai estimasi parameter, maka langkah selanjutnya adalah melakukan uji normalitas residual.Pengujian kenormalan residual menggunakan ujiKolmogorov-Smirnov dengan hipotesis sebagai berikut:

$H_{0}$ : Residual berdistribusi normal

$H_{1}$ : Residual tidak berdistribusi normal

\section{Regression Analysis: Mutlak Residual versus $x$}

The regression equation is

Mutlak $=4.28+0.0295 x$

Analysis of Variance

Source $\quad D F \quad S S \quad M S \quad F \quad P$

$\begin{array}{lllllll}\text { Regression } & 1 & 2.81 & 2.81 & 0.15 & 0.698\end{array}$

Residual Error 28512.4518 .30

Total 29515.26

Durbin-Watson statistic $=2.101308$

1. Uji identik dengan hipotesis sebagai berikut.

$H_{0}: \sigma_{1}^{2}=\sigma_{2}^{2}=\ldots=\sigma_{n}^{2}=\sigma^{2}$

$H_{1}$ : minimal ada satu $\sigma_{i}^{2} \neq \sigma^{2}, \quad i=1,2, \ldots, n$

Pada tingkat signifikansi 5\%.Nilai $\mathrm{F}_{\text {hitung }}=0.15<\mathrm{F}_{\text {tabel }}=4.18$ atau dapat dilihat nilai P-value $0.698>\alpha=0.05 y$ ang menyimpulkan bahwa dalam kasus ini varians telah homogen.

2. Uji independen

Uji independen dapat dilakukan dengan hipotesis sebagai berikut.

$H_{0}: \rho_{i}=0$ atau residual tidak berkorelasi

$H_{1}: \rho_{i} \neq 0 \quad$ residual berkorelasi 
$\alpha=0,05$

Durbin-Watson statistic $=2.101308$

Pada tingkat signifikansi 5\%.Nilai P-value $=0.698>\alpha=0,05$ yang menyimpulkan bahwa dalam kasus ini residual tidak berkorelasi atau gagal tolak $\mathrm{H}_{0}$. Dengan kriteria Durbin Watson tes $d=2.101308 \square 2$ tidak ada korelasi antar residual.

3. Uji normalitas

Pengujian normalitas dapat dilakukan dengan hipotesis sebagai berikut.

$H_{0}$ : Residual berdistribusi normal

$H_{1}$ : Residual tidak berdistribusi normal

\section{Gambar 4.1 Plot residual}

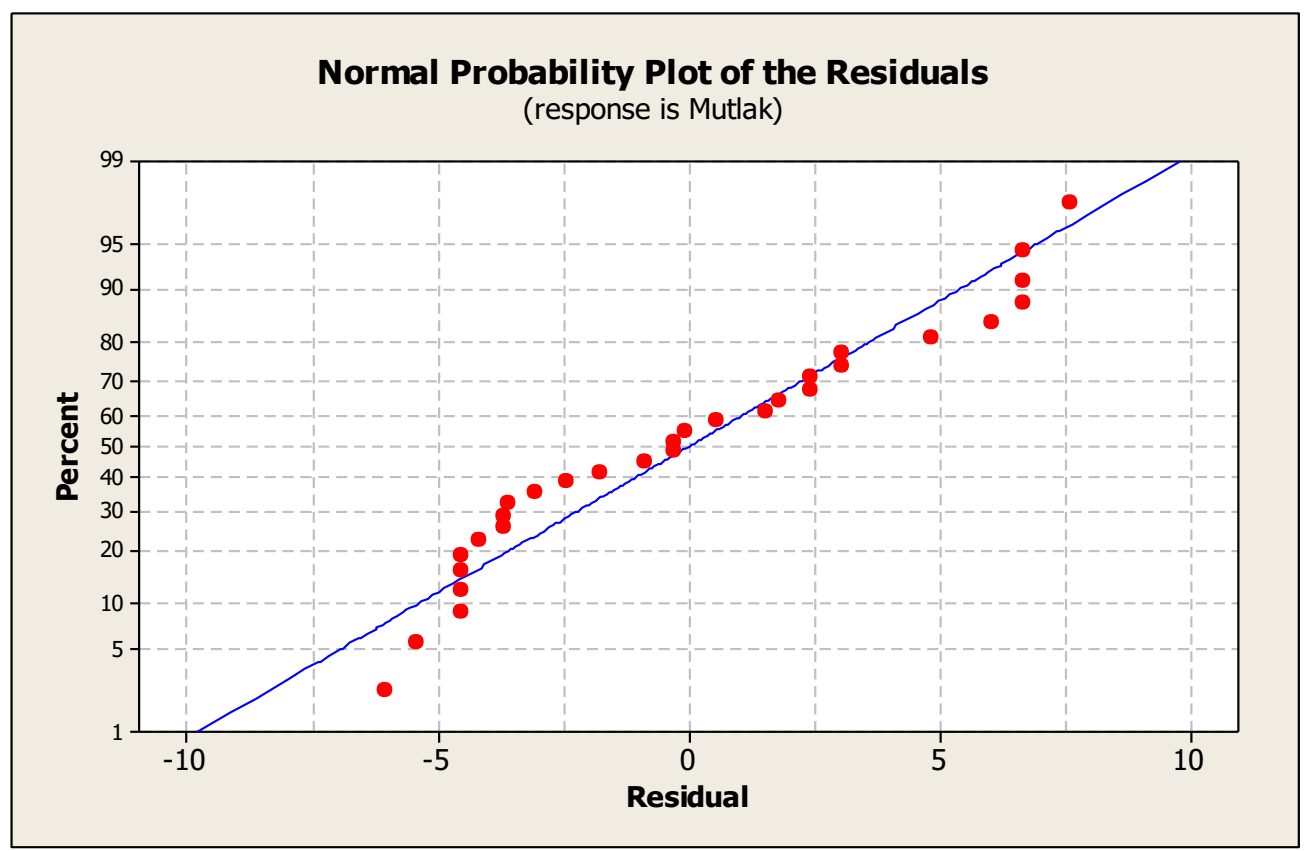

Plot normalitas residual menunjukkan tidak ada penyimpangan terhadap distribusi normal. Hal ini diperkuat dengan menggunakan uji Kolmogorov-Smirnov yang memberikan Pvalue $=0.698>0.05$ sehingga gagal tolak $\mathrm{H}_{0}$ atau residual berdistribusi normal .

Perebedaan penelitian ini dengan penelitian Fitria (2012) pada hasil penelitiannya menunjukkan adanya peningkatan partisipasi siswa. Hal itu dapat dilihat dari 1) Keberanian mengajukan pertanyaan sebelum diadakan tindakan sebesar 12,9\%, dan di akhir tindakan mencapai 45,16\%. 2) Mengerjakan soal di depan kelas sebelum tindakan sebesar 19,35\%, dan di akhir tindakan mencapai $41,93 \%$. 3) Keberanian menjawab pertanyaan guru sebelum tindakan sebesar $16,13 \%$, dan di akhir tindakan mencapai 51,61\%. 4) Keberanian siswa menanggapi jawaban siswa lain sebelum tindakan sebesar 16,13\%, dan di akhir tindakan mencapai 41,93\%. Hasil tes tertulis yang dilakukan sebelum dan sesudah penelitian menunjukkan adanya 
Metode Pembelajaran Snowball Drilling Untuk Materi Relasi dan Fungsi Pada Siswa Kelas VIII MTs. Negeri Ngada Eni Syafitri ${ }^{1}$ Gregorius Taga ${ }^{2}$, Stefania Baptis Seto ${ }^{3}$

Jupika: Jurnal Pendidikan Matematika, Volume 4. Nomor 1. Maret 2021. Hal. 42-51

peningkatan pada prestasi. belajar siswa. Sebelum adanya tindakan kelas prestasi belajar siswa hanya mencapai daya serap 60\%, sedangkan di akhir tindakan prestasi belajar siswa mencapai daya serap 96,77\%. Penelitian ini juga berbeda dengan penelitiannya Hartono (2018), yang Hasil penelitian menunjukkan bahwa perhatian siswa pada pembelajaran menggunakan model think pair share dan snowball drilling pada tahap pra tindakan, siklus I, dan siklus II mengalami peningkatan dilihat dari segi proses maupun hasil. Pada tahap pra tindakan persentase perhatian siswa dilihat dari hasil lembar observasi sebesar 37,52\%, sedangkan dari hasil angket sebesar 53,23\%. Pada siklus I persentase perhatian siswa dilihat dari hasil lembar observasi meningkat menjadi 59,49\%, sedangkan dari hasil angket meningkat menjadi 64,28\%. Pada siklus II persentase perhatian siswa dilihat dari hasil lembar observasi meningkat menjadi 79,49\%, sedangkan dari hasil angket meningkat menjadi 80,84\%.

Dari beberapa penelitian bahwa penerapan metode Snowball Drilling Untuk Meningkatkan Hasil Belajar siswa.

\section{KESIMPULAN}

Berdasarkan uraian penjelasan pada bab IV maka dapat diambil kesimpulan sebagai berikut:

1. Dari pengembangan perangkat pembelajaran, dihasilkan perangkat pembelajaran snowball drilling untuk materi relasi dan fungsi dengan kategori baik karena telah memenuhi syarat validitas, reliabilitas, dan sensistivitas. Perangkat pembelajaran yang dimaksud adalah Rencana Pelaksanaan Pembelajaran (RPP), Lembar Kerja Siswa (LKS), dan Tes hasil Belajar (THB).

2. Berdasarkan hasil analisis kovarian diperoleh $\mathrm{F}_{\text {hitung }}=17.43823$ dengan dk pembilang $=1$ dan $\mathrm{dk}$ penyebut $=27$ pada taraf signifikansi $(\alpha=0.05)$ memberikan nilai $\left(\mathrm{F}_{\text {tabel }}=4.21\right)$. Jadi nilai $\mathrm{F}$ hitung $>\mathrm{F}$ tabel artinya $\mathrm{H}_{0}$ ditolak dan $\mathrm{H}_{1}$ diterima. Hal ini menunjukan bahwa pembelajaran snowball drilling dapat meningkatkan hasil belajar untuk materi Relasi dan Fungsi pada siswa kelas VIII MTs. Negeri Ngada Tahun Pelajaran 2020/2021.

\section{DAFTAR PUSTAKA}

Arifin, Z. (2012). Penelitian Pendidikan dan Paradigma Baru. Bandung: Remaja Rosda Karya.

Fitria, A. A. (2012). Penerapan Metode Snowball Drilling Sebagai Upaya Untuk Meningkatan Partisipasi Siswa Terhadap Pembelajaran Matematika. Skripsi. Universitas Muhammadiyah Surakarta.

Hartono, B.P. (2018). Penerapan Model Pembelajaran Think Pair Share dengan Metode Snowball Drilling untuk Meningkatkan Perhatian Siswa. Jurnal Edumatics. Vol. 8 (1). Hal 9-16 
Haryani, S., Sukasno \& Friansah D. (2015). Penerapan Metode Snowball Drilling Pada Pembelajaran Matematika Siswa Kelas VIII SMP Negeri H Wukirsari. Jurnal Elektronik Pembelajaran Matematika. Vol. 2 (7). 758-770.

Kurtner, M. H., dkk. (2005). Apllied Linier Regression Models. 5th Ed. Mc.Graw-Hill Companies. New York.

Larasati, R.., Susilowati, E. \& Indriyanti, Y.N. (2020). Efektivitas Model Pembelajaran Snowball Throwing dan Snowball Drilling terhadap Prestasi Belajar Ditinjau dari Keaktifan Belajar Siswa pada Materi Pokok Hidrolisis Garam kelas XI MIPA di salah satu SMA Swasta Kabupaten Karanganyar. Jurnal Pendidikan Kimia. Vol 9 No. 2

Mulyasana, D. (2011). Pendidikan Bermutu dan Berdaya Saing. Bandung: PT.Remaja Rosda Karya.

Ningsih, E. F., Mardiyana \& Iswahyudi, G. (2014). Eksperimentasi Model Pembelajaran Kooperatif Tipe Team Assisted Individualization (TAI) Dengan Metode Snowball Drilling Terhadap Prestasi Belajar Matematika Ditinjau dari Kemandirian Belajar. Jurnal Elektronik Pembelajaran Matematika. Vol. 2 (7). Hal 758-770.

Prabu, A.M. (2011). Metode-Metode Pembelajaran. Semarang: PT. Angin.

Sugiyono. (2010). Metode Penelitian Pendidikan Pendekatan Kuantitatif, Kualitatif dan $R \& D$. Bandung: Alfabeta.

Suprijono, A. (2014). Cooperative Learning Teori \& Aplikasi Paikem. Surabaya: Pustaka Pelajar.

Suyono \& Hariyanto. (2011). Belajar dan Pembelajaran. Bandung: PT. Remaja Rosdakarya.

Yanto, D. (2014). Penerapan Model Pembelajaran Tipe Snowball Drilling untuk Meningkatkan Prestasi Belajar Antropologi Siswa Kelas XI Bahasa SMAN I Tawangsari Sukoharjo Tahun Pelajaran 2013/2014. Skripsi. Universitas Sebelas Maret Surakarta. 